\title{
The Relationship between Religion and State According to the Perspective of K.H. Zainal Arifin Abbas
}

\author{
Rizki Pristiandi Harahap", Syahrin Harahap ${ }^{2}$, Hasan Bakti Nasution ${ }^{2}$ \\ ${ }^{I}$ Ph.D Student in State Islamic University of North Sumatera, Medan, Indonesia \\ ${ }^{2}$ Lecturer in State Islamic University of North Sumatera, Medan, Indonesia \\ rizkituasan@gmail.com
}

\begin{abstract}
In-depth study of the relationship between religion and the State (Politics) until now is considered to be very relevant, because until now and even in the future this issue has the potential to continue to have heated debates and could become the root of conflict from various groups, both at the level world countries, large institutions as well as in small communities in every corner of the village. Because the issue of both relation is still considered to be turbulent with diverse human understandings, K.H. Zainal Arifin Abbas, known as an Islamic politician and charismatic Islamic thinker from North Sumatra, negated that ideally the relationship between Religion and State should be integrated in each country, because according to him this relationship is interlocked, in religious teachings (Islam) teaches a lot of the concept of ethics in the state or (politics), then in carrying out political activities very much needed ethics or ways of doing politics.
\end{abstract}

Keywords: Politics; religion; state; K.H. Zainal Arifin Abbas.

\section{Introduction}

When viewed globally and universally the relationship between Religion and State until now has been judged as if it had not found a common ground (discourse). Because in some countries in the world there are still conflicts because of this relationship issue, even though these two relationships can be said to be blood relations. Of course human nature has diverse thoughts so that these two relationships are still seen in a variety of choices, some view the relationship of Religion and State as one (integral), some view as separately (secular), and there are also some view as not united and not separate (symbiotic). All of these view paradigms are certainly considered to have advantages and disadvantages for every community that adheres to it. Even in Indonesia itself as a country that has many religions, ethnicities, and cultures (Multiculturalism) considered not to have a uniform view of their choices in seeing these two relationships even though Islam as the majority religion is adopted.

From the lower classes of Indonesia society in general and among Muslims in particular still continue to reap the pros and cons, it means that not all are able to accept integratedly, even more some community groups and some Muslims, some consider that the paradigm of their perspective in viewing the relationship between religion and State is separate (secular), by saying that religion is basically holy or clean from negative process issues while politics is considered dirty or can do any activity by doing various ways without regard to the process of how to achieve it, so that it can lead to controversial opinions among various groups of people, there is also another part of the community opinion that says that this relationship can trigger a source of disunity among fellow children, or vice versa there also those who assess this relationship are able to strengthen relations between one another in establishing harmony between people in the context of the nation and state.

Indonesia is well known by all countries of the world about its diversity or multireligion, ethnicity, and race, it means that the Indonesian people are not only inhabited by one religion but many religions, tribes and customs exist. Quantitatively, it is undeniable that 
Indonesian society is the majority community who adheres to Islam, so that it is considered very difficult to actually unify the understanding of Muslim thought, especially to the stage of separating the desires of the concept of the majority of the people with the Islamic Sharia legal system that wants to be applied in Indonesia. Actually the teachings of Islam have taught many concepts of benefit through the Koran, for example the sentence which negates that Islam Rahmatan Lil'alamin which means that Islam gives mercy (coolness) to all residents in the world including animals, plants and all human beings whatever their beliefs .

But actually, it is essential that every religion is certain to have noble and good teachings when referring to the source of the teachings. Of course there is no religion whatsoever religion that invites his people to want to commit crimes or that harms humans, surely every religion always invites people in matters of good, both in relation to God (Hablumminallah) and its relationship to fellow human beings themselves (Hablumminannas). It's just that if there are people who commit crimes in the name of religion that are clearly outside the teachings or concepts of religion, then it is not one of the religions but human beings who are wrong in understanding and interpreting the understanding of their religion to be applied in their lives.

\section{Discussion}

\subsection{Understanding the Meaning of Religion and State.}

Before discussing more deeply what religion and state here must first understand fundamentally according to linguistics, in this case religion (Din) is divided into two words, first "A" which means No, and "Gama" means chaotic or leaving. Then as a whole "Agama" can be interpreted to mean "Not Messy or Not Going", while in terms that religion can be interpreted by a deep human belief with heart and deeds to his God to avoid cruel acts and lead him to the path of truth and safety of the world and the afterlife. Whereas the meaning of the language in a language is often termed the word State, while literally in the Indonesian dictionary the State means an organization in an area that has the highest authority that is legitimate and is obeyed by the people or the people.

Even the teachings of Islam have been explained through the Koran which confirms that the religion of truth is only the religion of Islam (QS. 3:19). Philosophically it means that there is not a single sentence in the Koran affirming that religion other than Islam is the most correct religion. The intention here is correct to be guided by Muslims so that their teachings can be thoroughly implemented (kaffah). Ideally indeed, the State must be able to facilitate religious components, for example in the context of establishing houses of worship, carrying out religious holidays, whether it be Islam, Christianity, Hinduism, Buddhism, or mosques, churches, temples, etc. The state must take part fully support as (Facilitator) in order to create harmony in the nation, especially if viewed from the historical side of Indonesian independence, it cannot be denied that Ulema, students and other religious leaders also participate in developing the birth of Indonesian independence, so it is very natural for the state to be present here in strengthening religious diversity which is especially in Indonesia.

Thus every human being must indeed be truly capable in interpreting religion and the State both in essence and philosophically. Because if humans are not able to understand the teachings and objectives of religion and state, it can trigger conflicts in both the vertical and horizontal order, because alluding to issues of religion or belief is very vulnerable and needs to be very careful. 


\subsection{Relationship between Religion and State in Islamic History.}

Islam has a brilliant history of civilization in dealing with government and state matters. In the context of Islamic history, this relationship was carried out by the Prophet Muhammad at that time in Medina. He made Medina as the initial basic capital in fostering character for the people who existed at that time in Medina, which would eventually become an Islamic State. Because it can be said that taking care of the community is also part of dealing with the problems of the State, the affairs of the State are also much concerned with the benefit of society. In addition, it is also undeniable that in the beginning the prophet Muhammad in forming an Islamic State was not only inhabited by a limited number of Islamic societies but also diverse communities from various existing tribes (heterogeneous).

One of the efforts made by the Messenger of Allah as the leader at that time was first, through the brotherhood of fellow believers, in this case also the Koran had confirmed that in fact the believers were brothers, that means all people who had faith in Allah SWT has a family relationship, of course through this apostle performs his political movement to take care of a country or society, he is not only able to unite one tribe and kabilah, but also able to unite through various tribes and diverse tribes that are often known by the term muhajirin and anshor .

Secondly to unite the community in the mosque, the mosque that functions is not only known as only carrying out the routine and activities of prayer and recitation, but is also used by the apostles as a place (central) in deliberation, formulating a war or political strategy, and making the mosque also as guidance mentally and spiritually for the generation of Islamic mujahids. In various hadiths it is also said that Muslims are like mosque poles, between one and the other must strengthen each other, must be able to share, and must help each other (ta'awun) with each other so that Muslims are strong and able stand firm against oppression.

\subsection{Relationship between Religion and State According to K.H. Zainal Arifin Abbas.}

To see clearly about the perspective of K.H. Zainal Arifin Abbas on the issue of the relationship between religion and the State, he must see the concept of his thought through various writings and movements of activities that he does while living in the world.

a. First, Ulama and Umara, in this view he defined Ulama as a person who has a high, broad, deep religious knowledge in accordance with his deeds and is afraid of Allah, whereas Umara is a leader in a religious organization or region. Islam and have broad knowledge and fear of Allah SWT. These two relations, according to him, should not be separated, meaning that between ulama and umara must reinforce and remind each other, or oars each other in the way of protecting their people. Because if these two relationships are not interrelated or separate then it can lead to chaos, because in leading an organization according to him must be close to the teachings of Islam or Quran and Hadith.

b. Second, State Basis, according to him the ideal State in Indonesia is sourced from the teachings of Islam itself, meaning that Islam is believed to be able to give me a sense of security and peace for religious life, Islam which has a universal nature does not merely teach about worship course in the form of prayer, fasting, almsgiving, alms, etc., but also teaches about the concepts of democracy, justice, deliberation, unity, diversity, and so forth. In this case it does not mean that he rejects Pancasila as the basis of the State, 
according to him Islam is appropriately interpreted according to Islam, and even the basis of the State of Pancasila is part of one said to be an Islamic State.

From the two perspective above, it can be concluded that, the relationship between religion and State is inferior to K.H. Zainal Arifin Abbas is more directed to the Integralistic paradigm or unification, it means that the relationship between religion and the State must not be separated, but must blend. To know more deeply about who the K.H. Zainal Arifin Abbas certainly has to know a little about his life.

\subsection{Life Biography K.H. Zainal Arifin Abbas}

Zainal Arifin Abbas is a good and intelligent child from the couple Muhammad Abbas and Rajiah, he belongs to the category of youth who obey Allah and obey his parents and love his younger siblings and children, it is proven he often helps both parents and his younger siblings in earning a living and seeking knowledge, because he always realized that he was born in a state of wealth. Since he was a child he studied at a public school and went to an El-Hidayah Madrasah located in the area around the Pinang Baris road, Medan Sunggal. Since moving from children to adolescents he has been able to teach his juniors, he was raised from his parents who are devout Muslims. When he grew up he was involved in a variety of skills, not only capable as a preacher but he was also known as a charismatic scholar, intellectual, mufassir of the Koran, philosophers, politicians, thinkers, fighters, statesmen, and Islamic mujahids who came from North Sumatra. He is well known as the triad of scholars together with his teachers with Sheikh H. Abdul Halim Hasan and Sheikh Abdurrahim Haitami.

The three of them are the eight-volume writer of Al-Qur'an Karim Tafsir. K.H. Zainal Arifin Abbas was born in the all-round comfortable village of Deli Hilir, East Sumatra on 23 Rabiul Awwal 1330 H, coinciding on March 12, 1912 in Kampung Lalang, Serbanyaman District, now known as Kampung Lalang Village, Sunggal District, Deli Serdang Regency, Sumatra Province North. Subsequently he died at the age of 67 years precisely on September 16, 1979 after three days being treated at Medan Herna hospital and buried in the cemetery at Jalan Sei Batu Gingging Medan (in front of the Medan ministry of religion's office).

\subsection{Teachers and Students K.H. Zainal Arifn Abbas}

Since he was born and moved from children to adolescents and so on, he has his caliber and teacher teachers in terms of science and its application including Sheikh Fakih Said, Sheikh Fakih Saidi, Sheikh Abdullah Umar, Sheikh Sheikh H.M. Nur Ismail, Kiyai Abdul Karim Tamin, Sheikh Hasan Maksum, Sheikh Abdul Halim Hasan, etc. All of these teachers were very influential in shaping Zainal Arifin Abbas's attitude, personality, and silence from adolescence to adulthood in his activities, so that his character forged him into an excellent Islamic mujahid. While his students who are still alive today are Prof. Dr. Abdullah Syah. MA (Chairman of North Sumatra MUI), Prof. Hasbalah Thaib. PhD. Prof. Dr. Usman Pelly (Professor from UNIMED), and many more.

\subsection{K.H's Works Zainal Arifn Abbas}

Karel A Steenbrink, known as western scientist, positioned K.H. Zainal Arifin Abbas as a reformist Kufassir of the Qur'an or equivalent to Prof. Hamka In addition, he also wrote many of his phenomenal writings including the Interpretation of the Holy Qur'an, Muhammad's Life Fairy or the History and Struggle of the Prophet Muhammad, The 
Development of Religious Thoughts, the Book of Prayer, the Guide to Prayer, Sufism, and many more writings in various articles- the articles published in various Islamic Magazines at that time were of various interesting titles and themes. All of his works are not only published domestically, but have also been published and reproduced abroad in this case in Malaysia. In his writing literature he also quoted a lot from national politicians such as Muhammad Natsir.

In the principle of religion according to Shaykh.K.H. Zainal Arifin Abbas must not be gray, must be bright or must be seen which is right and which is false. But that does not mean at all Shaykh.K.H. Zainal Arifin Abbas wanted to rebel the legitimate government (Bughat), but he strongly criticized Nasakom's peham initiated by Bung Karno because he considered it was not in line with the values of Islamic teachings. In this realm, it can also strengthen the view of Syekh.K.H. Zainal Arifin Abbas regarding the relationship between religion and the State, his views and thoughts clearly lead to an Integralistic paradigm or unification. In addition, this Nasakom understanding can be interpreted as a secular understanding that wants to deliberately separate Islam (religion) and Politics (the State). In addition, according to the writer, this understanding is considered as the root of the existence of the PKI in Indonesia who wants to eliminate the understanding of Islam from the land of Indonesia. this is very much in line with the decision of the Indonesian People's Consultative Assembly's MPR which forbids PKI to exist again in Indonesia. it can even be generalized by the majority of Indonesian people who reject the notion that communism exists and reappears in Indonesia.

In Indonesia, in particular the PKI as a communist party had experienced its glory around 1965-1967 under the government of President Sukarno, the supreme chairman of the PKI at that time was led by Dipa Nusantara Aidit or often abbreviated as D.N. Aidit The leader of this organization was considered to be very closely related to Soekarno, moreover this organization had given a bad impression to the ulama, santri. Indonesian Army and all Indonesian people, because they seemed to want to eliminate the understanding of religious elements in the Indonesian motherland. and it was proven by the tragedy of the September 30 1965 movement with the brutal killing of Generals from the Indonesian Army (Heroes of the Revolution), this event gave a philosophical picture that the PKI, which had a secular ideology, wanted to forcibly separate religion and state relations, which later understood they were true. get rejection from various circles of the people of Indonesia. this shows evidence that secularism is not suitable to be crowned for the nation of Indonesia which is known as the majority adheres to Islam.

Not only in Indonesia as a Muslim majority, in any country if the people have a majority religion then the State must provide added value to the majority of the people. For example, in Germany, there is an area there that has a majority of religion other than Islam, so their country gives more rules to the religion. For example, the sound of the call to prayer in the mosque may not be stronger than the sound of the bells of the Church, because it is considered to be disturbing for those who want to perform their worship, all of which is done to respect the majority of people who are in the area. All of this has the aim to give meaning to the benefits of harmony and peace in the midst of the community.

It cannot be denied that the independence of a country is strongly influenced by its people from a variety of ideas, various existing ideas are able to give spirit to its struggle against the invaders. But it cannot be separated from what religion has a majority in that State, because the majority religion is able to provide a strong doctrine to the people or 
worshipers who are considered to have a vision, mission, and purpose in fighting to fight from the undermining of different ideologies of Indonesia.

\section{Conclusion}

Based on the information and analysis above, in this case the writer can conclude that the perspective of K.H. Zainal Arifin Abbas about the relationship between religion and the state is to be integrated or integrated, meaning that the relationship between religion and the state must be united and must not be seen separately from his thoughts, First, about ulama and umara which according to him must be in line because between ulama and umara must strengthen each other, Second, KH Zainal Arifin Abbas rejects Nasakom's understanding which is considered to eliminate elements of the value of his religious teachings, he wants Islam to be present in the ideological understanding of the nation and state, even according to him, Pancasila is already included as an element of the conditions to become an Islamic State.

\section{References}

Abbas, Zainal Arifn. (1977). Ilmu Thasawuf, Malaysia: Pustaka Amani Press, 1977. , (1962). Kitabus Shalat Medan: Firma Rahmat, 1962. , (1963). Peri Hidup Muhammad, Medan: Firma Rahmat, 1963.

Harahap, Syahrin. Jalan Islam: Menuju Islam Paripurna (Jakarta: Kencana), 2016. , (2016). Agama Syumul: Membangun Muslim Komprehensif . , (2011). Metodologi Studi Tokoh Pemikiran Islam Jakarta: Prenada Media.

Nasution, Hasan Bakti. (2012). Filsafat Pergerakan Islam, Bandung: Cita Pustaka Media Perintis.

Arkoun, Mohammed. (1994). Rethinking Islam, United State of America: Westview Press.

Azra, Azyumardi. (1999) Konteks Berteologi di Indonesia, Pengalaman Islam, Jakarta: Paramadina.

Effendy. (1998). Bahtiar. Islam dan Negara: Transformasi Pemikiran dan Praktik Politik Islam di Indonesia. Terj. Ihsan Ali-Fauzi. Jakarta: Paramadina, 1998.

Marijan. (1992). Kacung. Quo Vadis NU: Setelah Kembali ke Khittah 1926. Jakarta: Erlangga. 